\title{
Cégep de Sainte-Foy/Cégep de Rimouski
}

\section{Une cérémonie de remise des joncs exceptionnelle pour souligner l'année internationale des forêts}

a cérémonie de remise des joncs aux 1 finissants des programmes de technologie forestière du Cégep de SainteFoy et du Cégep de Rimouski a eu lieu le vendredi 13 mai au Cégep de SainteFoy à Québec. Cette cérémonie en l'honneur de la relève des technologues forestiers a permis de clôturer en beauté le premier colloque à l'intention des technologues forestiers du Québec, organisé par Jean Dunnigan et Danielle Babin du Cégep de Sainte-Foy, afin de souligner l'année internationale des forêts. Sous le thème Technologue forestier : une expertise à partager, le programme de la journée comprenait, entre autres, des témoignages de technologues forestiers de carrière ainsi que des conférences prononcées par les acteurs engagés dans la mise en œuvre de la nouvelle Loi sur l’aménagement durable du territoire forestier du Québec. En prime, les étudiants participants ont eu loccasion déchanger avec des employeurs du milieu forestier venus présenter leur entreprise. Ce colloque a été une réussite puisque 120 personnes ont participé à lensemble de la journée.

Au cours de la cérémonie, animée par Martin Dupuis, coordonnateur de programme au département des technologies du bois et de la forêt du Cégep de Sainte-Foy, 27 joncs ont été remis aux finissants des programmes de technologie forestière du Cégep de SainteFoy et du Cégep de Rimouski qui avaient fait le déplacement pour la journée. Cet évènement a également été loccasion de donner leurs médailles dor aux récipiendaires 2011 des deux Cégeps, soient Patrick Perreault pour le Cégep de Rimouski et Véronique Delisle pour le Cégep de Sainte-Foy. Pour terminer cette cérémonie exceptionnelle, plusieurs bourses ont été remises aux étudiants : trois bourses détudes du Conseil de l'industrie forestière du Québec (CIFQ), le porte-parole de l'industrie forestière au Québec,

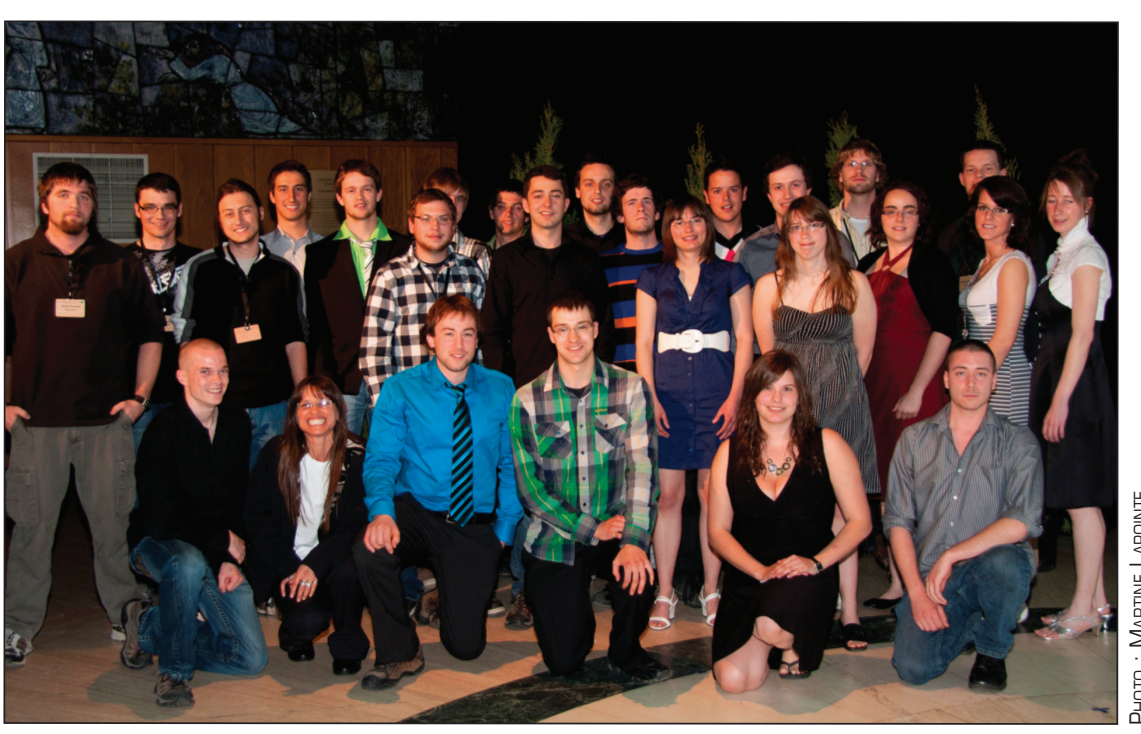

Les finissants du Cégep de Sainte-Foy et du Cégep de Rimouski heureux et fiers de recevoir leurs joncs

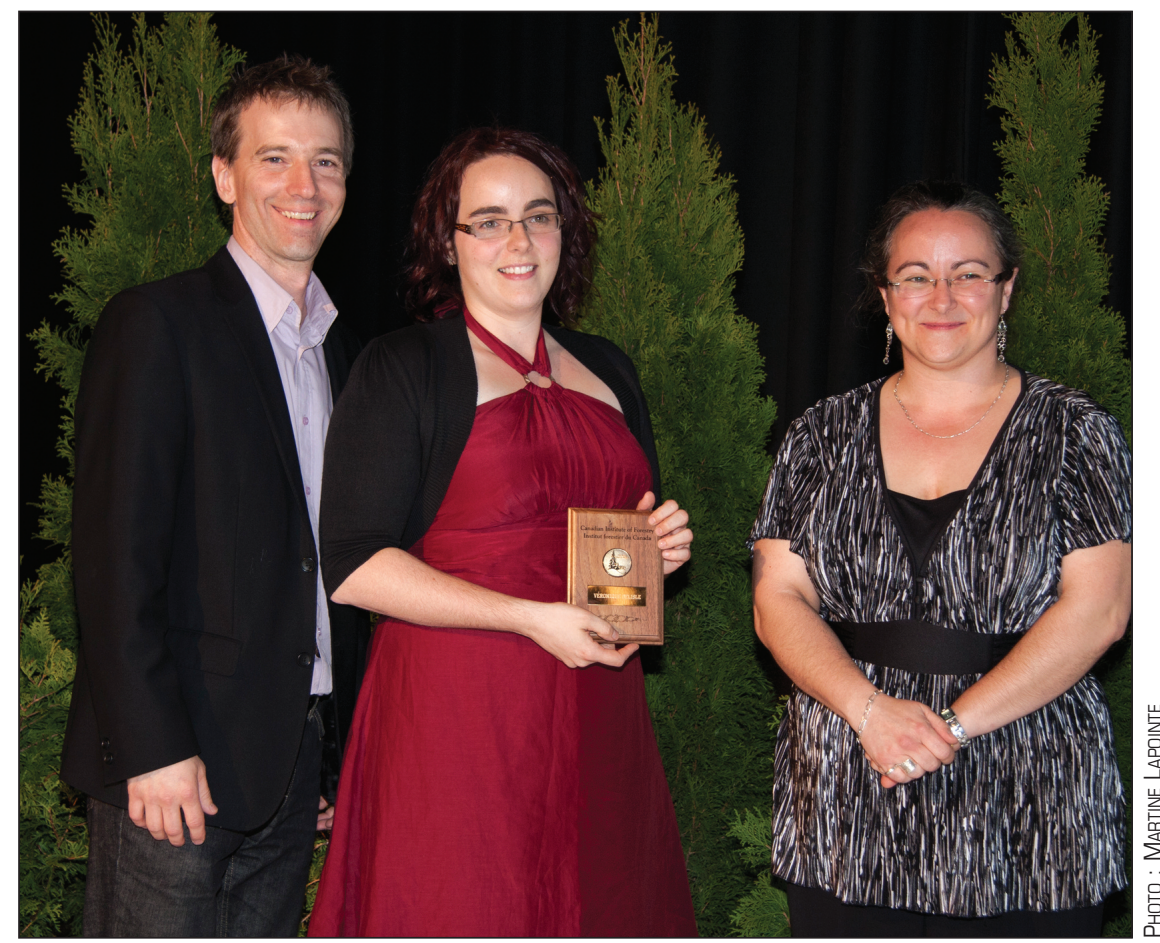

Véronique Delisle, récipiendaire 2011 de la médaille d'or de l'IFC pour le Cégep de SainteFoy, entourée de Martin Dupuis, coordonnateur de programme au département des technologies du bois et de la forêt du Cégep de Sainte-Foy et de Sylvie Carles, directrice de la section Orléans de l'IFC/CIF. 
représenté par $\mathrm{M}$. Florent Boivin, directeur adjoint au CIFQ ainsi que la Bourse REXFORÊT de l'Ordre des technologues professionnels du Québec (OTPQ) remise par M. Marc Lamontagne, directeur général de REXFORÊT et $M$. Richard Legendre, vice-président aux affaires professionnelles de l'OTPQ. On peut souligner que la récipiendaire 2011 de la médaille d'or de l'IFC, Véronique Delisle, s'est aussi vue attribuer la bourse de $1000 \$$ du CIFQ pour souligner sa réussite académique et son implication remarquable. Ces bourses en argent permettront de compléter la fortune que les finissants ont acquise en accumulant des connaissances tout au long de leur programme et qui, pour reprendre les mots de Félix Leclerc cités par Martin Dupuis, est maintenant plus à l'abri dans leur tête que dans un sac.

Texte écrit par Sylvie Carles, directrice de la section Orléans

Texte de présentation du récipiendaire M. Patrick Perrault

Lorsque le moment fut venu pour moi de m'inscrire au Cégep, je navais qu'un choix en tête, la foresterie. Intéressé par ce domaine pour diverse raisons telles que mon intérêt pour la forêt et le fait que mon père soit lui-même un technicien forestier, je n'ai pas regretté mon choix. Ayant déjà de l'expérience en foresterie grâce à mon père, jaai eu beau-

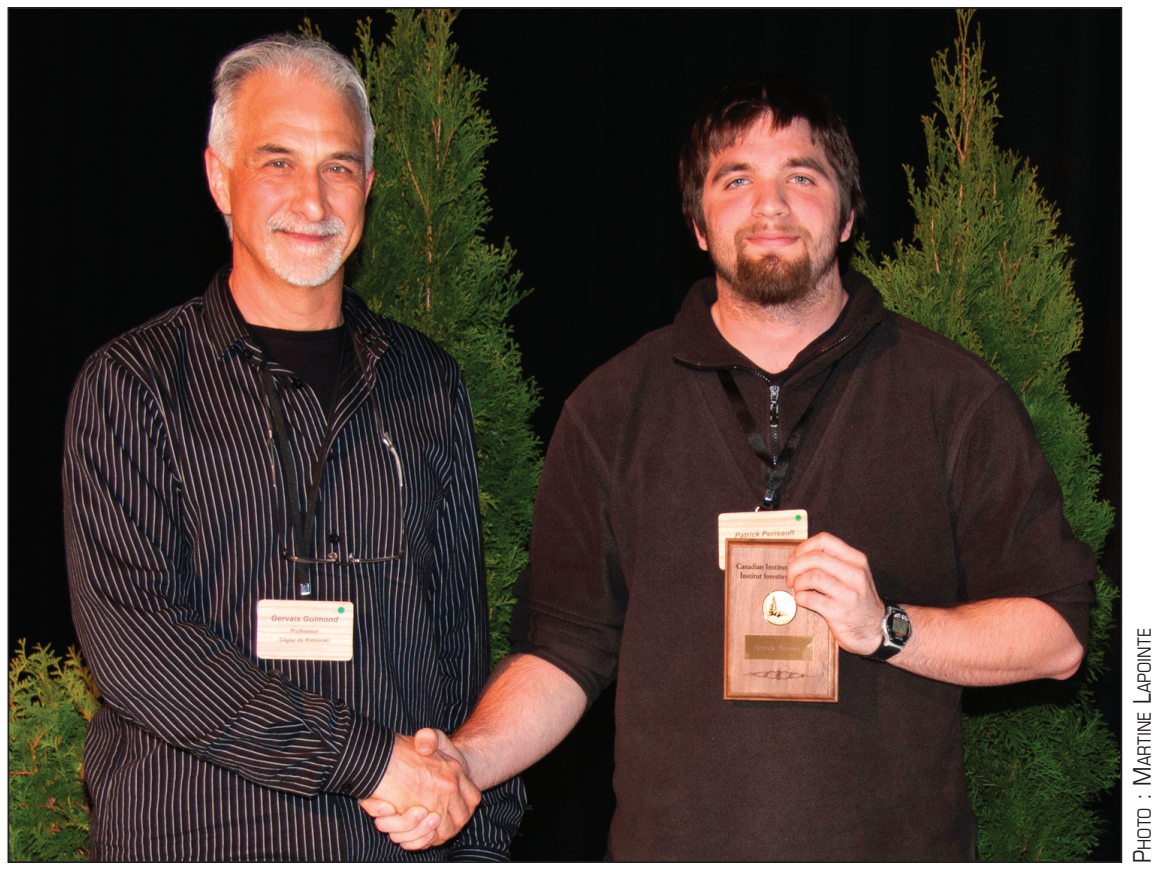

Patrick Perreault, récipiendaire 2011 de la médaille d'or de l'IFC pour le Cégep de Rimouski, félicité par Gervais Guimond, coordonnateur du département de foresterie du Cégep de Rimouski.

coup de facilité à assimiler les notions et connaissances durant les cours. Dès le premier été, j’ai été engagé par la SOPFIM et j’y ai travaillé pendant les deux étés de mon DEC ce qui ma permis de consolider mes connaissances.

$\backslash$ Me voici donc à la fin de mon DEC, je suis déjà engagé à la SOPFIM et jespère pouvoir my établir pour plusieurs

\section{Cegep de Sainte-Felicien}

ébastien Ouellette, finissant en amé$\checkmark$ nagement de la ressource forestière (programme des techniques du milieu naturel) au Cégep de Saint-Félicien, s'est mérité la médaille de l'Institut forestier du Canada.

«Les raisons qui mont poussé à m'inscrire à ce programme sont en lien avec mon amour des grands espaces et ma soif de connaissances relatives au milieu naturel. Je suis quelqu'un qui apprécie être à l'extérieur et vivre les saisons. J'aurais pu travailler comme technicien de la faune, mais j’apprécie beaucoup l'idée d'aménager les écosystèmes pour les générations futures. C’est justement ce que fait aujourd'hui la foresterie. Avant de m'intéresser à ce monde, je croyais à tort et comme beaucoup de gens, que la forêt était maltraitée et exploitée de façon inadéquate. C'est en m'informant et en suivant ce cours que j’ai changé ma vision de l'exploitation forestière. Si on veut que les choses changent, il faut le faire soit même et ne pas attendre que les autres le fassent à notre place.

La foresterie est la réponse aux interrogations de notre époque; les aménagements tiennent compte de tous les aspects d'un écosystème (sol, faune, flore, climat, topographie, perturbations naturelles, etc.) et des préoccupations des utilisateurs de la forêt. Nous sommes loin du temps où on récoltait la matière ligneuse sans se soucier du reste. De nos jours, la préservation des espèces menacées, la villégiature, la captation de carbone, la préservation de la qualité de l'eau et de l'air sont tous des défis que la foresterie moderne s'engage à relever.

Il faut saluer les efforts qui ont été consentis pour améliorer les pratiques années. Pour ce qui est de mes projets à long terme, l'achat d'un lot forestier est l'un de mes objectifs.

Patrick Perreault

Finissant en Technologie forestière Cégep de Rimouski

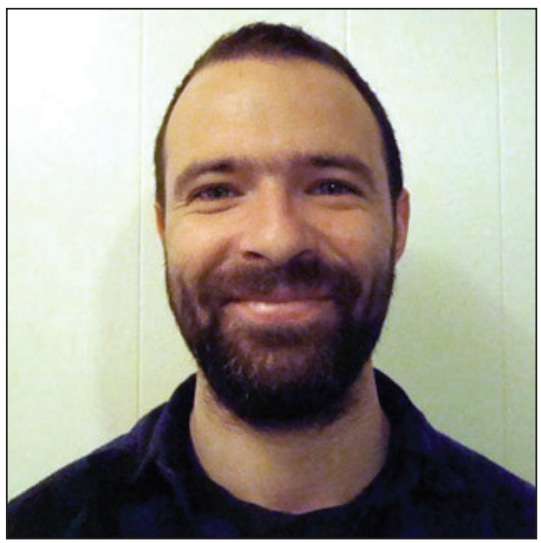

Sébastien Ouellette

de l'industrie. Il y a un souci de précision et d'efficacité en foresterie mais aussi une véritable volonté dêtre transparent vis-à-vis la communauté. Il n’y a pas beaucoup d'industries qui peuvent se vanter de gérer de façon durable leur ressource et de créer autant d'emplois.»

Sébastien débutera sa carrière au Saguenay-Lac St-Jean pour la firme FORESCO. On lui souhaite bonne carrière! 


\section{Université Laval}

a soirée de remise des joncs de l'Insti$\checkmark$ tut Forestier du Canada (IFC/CIF) aux 30 finissants 2011 au baccalauréat en aménagement et environnement forestiers et au baccalauréat coopératif en opérations forestières de la Faculté de foresterie, de géographie et de géomatique (FFGG) de l'Université Laval, a eu lieu le samedi 2 avril 2011 dans le cadre luxueux du Château Laurier à Québec. À la demande des finissants, la soirée était animée par M. Luc Bouthillier, professeur titulaire à la faculté et vice-président de la Section Orléans de l' IFC/CIF.

En plus des parents et amis des finissants, M. Robert Beauregard, doyen de la FFGG et M. Denis Villeneuve, président de l'Ordre des Ingénieurs Forestiers du Québec (OIFQ) étaient présents. La section Orléans étaient représentée par M. Luc Bouthillier, viceprésident, et Mme Sylvie Carles, directrice. Dans leurs discours, les invités officiels ont rappelé les défis et les opportunités qui attendent ces futurs ingénieurs forestiers diplômés un an après l'adoption de la Loi sur l'aménage-

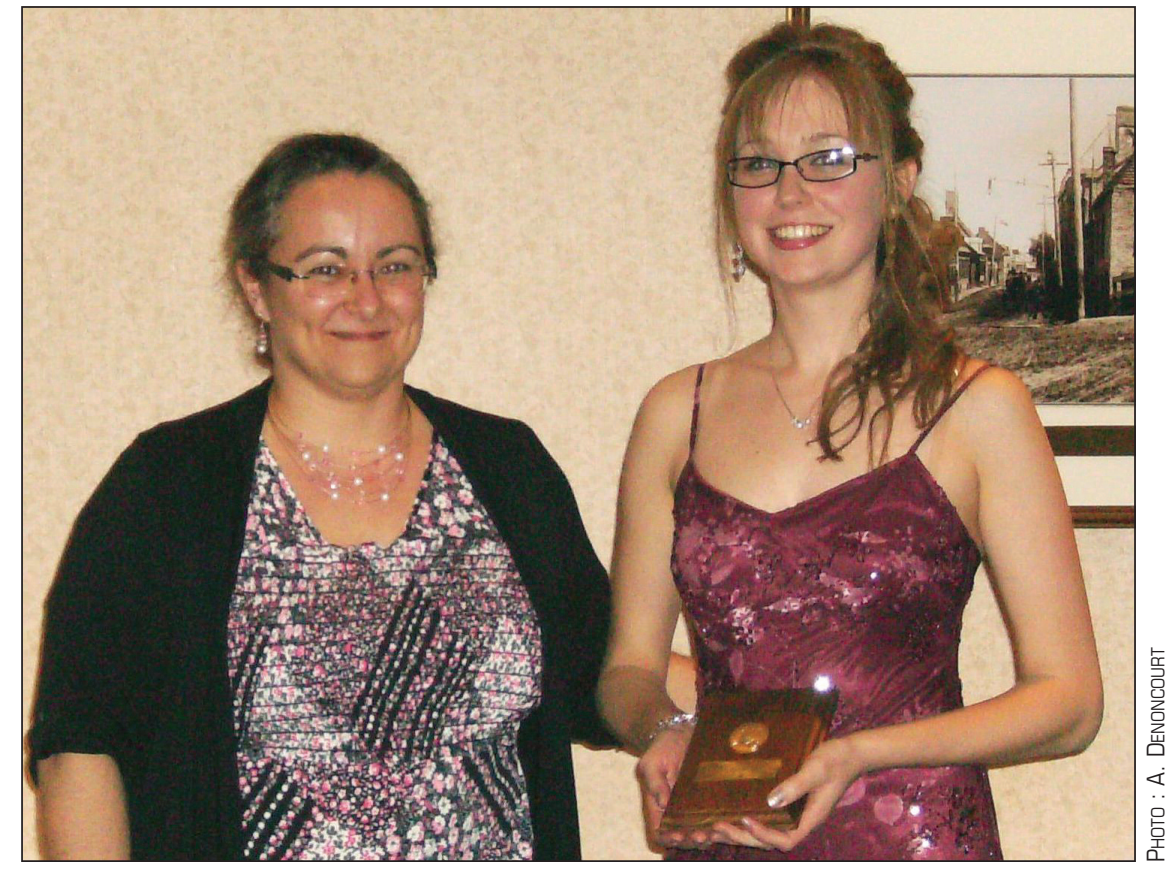

Amélie Denoncourt, récipiendaire de la médaille d'or de l'IFC/CIF au côté de Sylvie Carles, directrice de la section Orléans de l'IFC/CIF.

ment durable du territoire forestier qui réforme en profondeur le régime forestier au Québec.
Au cours de leurs allocutions, $\mathrm{M}$. Robert Beauregard et M. Denis Villeneuve ont notamment souligné le défi

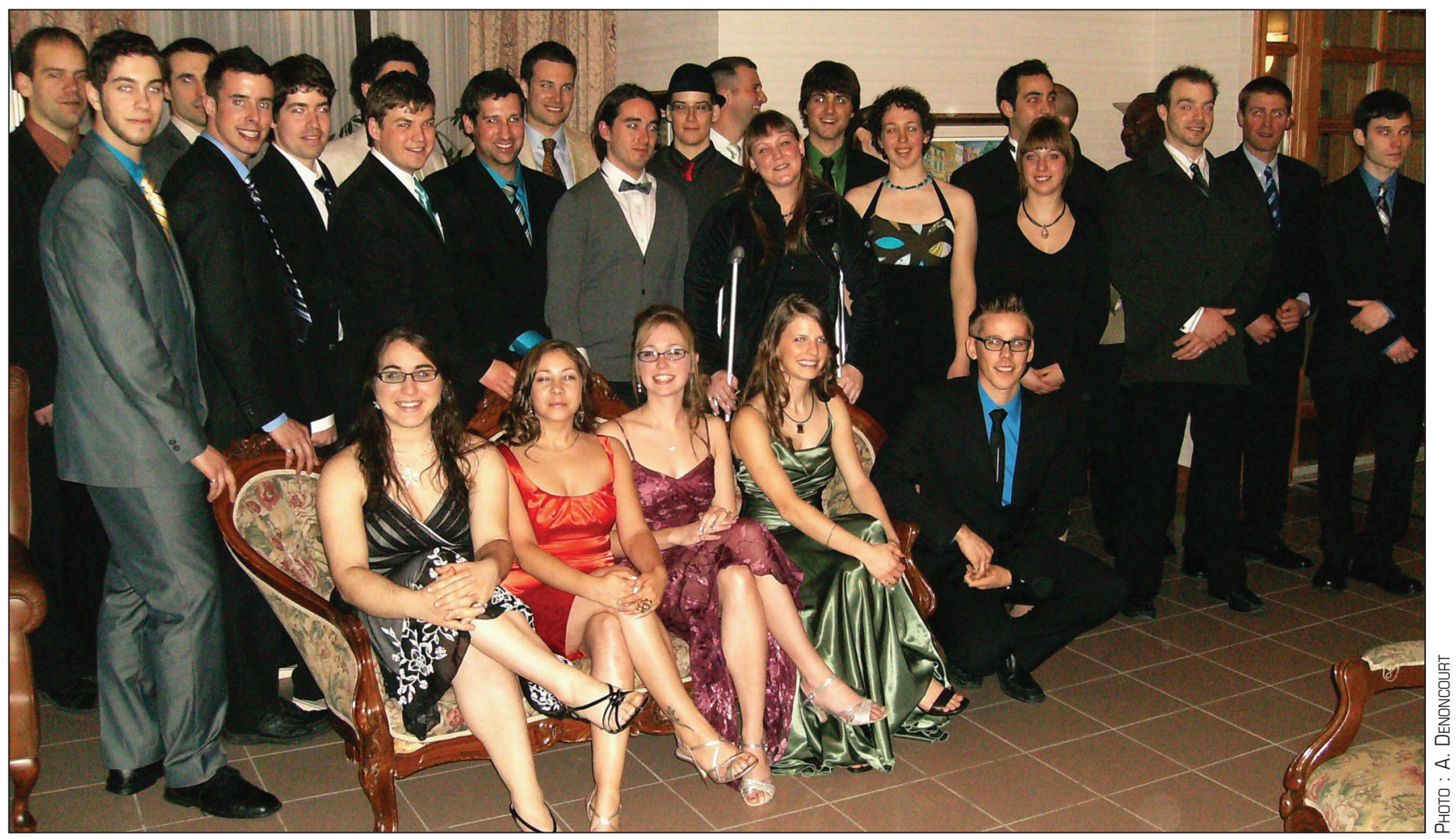

Les 30 finissants 2011 posent pour leur dernière photo tous ensembles. 
que représentera le fait d'être forestier dans un monde où, de plus en plus, le public souhaite protéger la nature, coûte que coûte. Ainsi, afin de réconcilier la consommation et la conservation de la nature auprès de la population, les futurs professionnels auront à rappeler et à démontrer continuellement qu'il est possible de produire une grande diversité de biens et de services tout en maintenant la pérennité et l'intégrité des forêts et de leurs fonctions. M. Denis Villeneuve a également encouragé les finissants à s'impliquer de façon à ce que les forestiers deviennent ceux qui expliquent au reste de la population ce qu'est vraiment la foresterie.

Ces interventions ont aussi été l'occasion de rappeler aux étudiants que si leur formation leur a fourni des connaissances de base requises pour l'exercice de leur profession, elle les aura aussi, et surtout, initiés à apprendre. Même diplômés, ils devront continuer à acquérir de nouvelles connaissances et à se former tout au long de leur carrière.

M. Luc Bouthillier a ensuite pris la

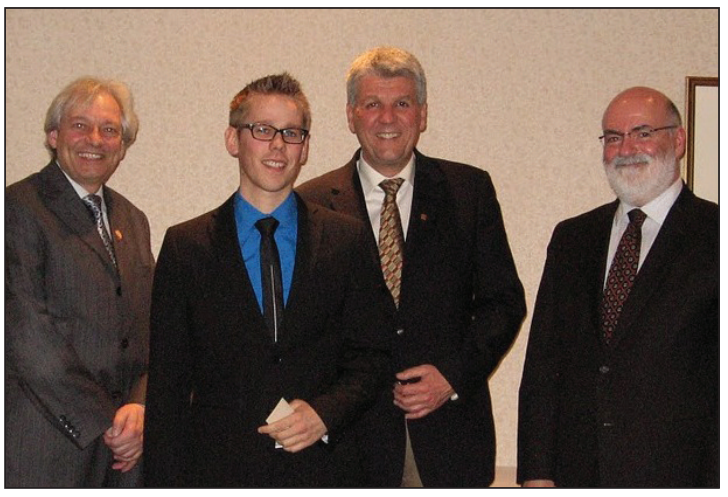

Vincent Chamberland, récipiendaire 2011 du prix de l'Ordre des Ingénieurs Forestiers du Québec (OIFQ), entouré, de gauche à droite, de Luc Bouthillier, professeur titulaire à la FFGG et vice-président de la Section Orléans de I'IFC/CIF, M. Denis Villeneuve, président de l'OIFQ et $M$. Robert Beauregard, doyen de la FFGG.

parole pour présenter l' IFC/CIF et le jonc. L'un comme l'autre, chacun à leur façon, permettent détablir un lien entre les différents professionnels de la forêt partout au Canada. Il leur a demandé de considérer ce jonc comme le symbole de leur engagement professionnel et passionnel envers la forêt.

En plus de la remise des joncs à chaque finissant, cette soirée a aussi été loccasion de remettre la médaille d'or de l' IFC/CIF à Amélie Denoncourt et le prix de l'OIFQ à Vincent Chamberland. Le prix de rayonnement décerné par la FFGG a été décerné à Sophie Delisle pour souligner sa contribution exceptionnelle dans le milieu associatif notamment.

La soirée a été clôturée par M. Luc Bouthillier qui a encouragé Ies étudiants à toujours garder en mémoire et à rester fidèle aux émotions qui les ont conduits à choisir cette profession. Pour faire face aux nombreux défis que réserve le monde en pleine évolution dans lequel on vit, il a également conseillé aux étudiants de s'inspirer de l'arbre présent sur leur jonc. En effet, l'arbre est continuellement exposé aux vents et autres intempéries et pourtant, grâce à ses racines, il tient toujours debout. Leur passion pour la forêt, les liens développés pendant les quatre années de leur bac avec leurs collègues et leurs enseignants, seront autant de racines qui les ancreront et les nourriront dans leur future vie de forestiers et de forestières.

Texte écrit par Sylvie Carles

\section{Sault College}

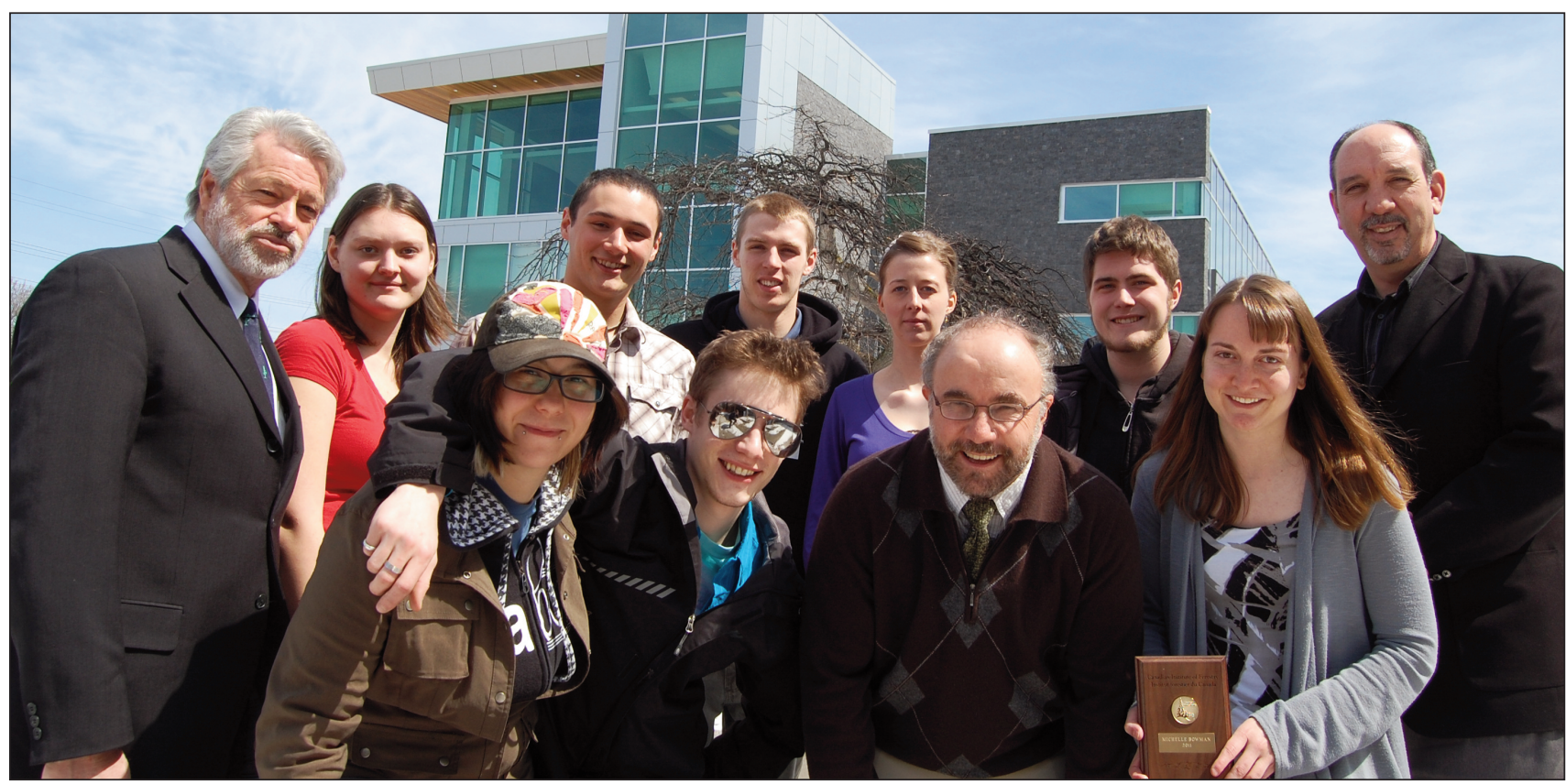

On April 18th upcoming graduates of the Forest Conservation program at Sault College participated in the annual CIF/IFC Silver Ring Ceremony. Al Cameron, Central Ontario Section Director, was on hand to present the rings. L-R back row: Al Cameron, Vicky Clarke, Adam Peck, Louis Fuchs, Amanda Syvret, Jeff Allan and Leo Tiberi; Front row: Ashley Robert, Kevin Tweedle, Professor John Clement and Section Councillor and Michelle Bowman, CIF/IFC gold Medal Recipient. 


\section{Sir Sanford Fleming}

The 2011 Silver Ring Ceremony for the graduating students of the Sir Sanford Fleming Forestry Technician Program was held at the Aucks Lodge on the Sir Sanford Fleming College Campus (SSFC) on March $26^{\text {th }}$.

Fifty-seven students received the Forestry Technician Silver Ring, presented by Mike Clarke of the Southern Ontario Section of the CIF/IOFC. Mike spoke about the importance, significance, and meaning that the ring symbolizes, not only to the recipient but also to the world of forestry past and present. Master of Ceremony was none other than the program coordinator at SSFC, Gerald Guenkel. The evening began with socializing, followed by an elegant and insightful introduction by Steve Munron, GM from Westwind Forest Stewardship Inc. Steve talked about the life lessons a forester learns over many years of life, work and learning.

A year in review synopsis was orated by Olivia Faulds and Michael Nandan with an eye-catching and memorable photo presentation, compiled by Car- olyn Towell, displayed in the background.

The Tree Marking Award was presented to Luke Oomen for his dedication to his studies and thirst for knowledge. Mr. Guenkel presented Acorn awards to numerous students for their dedicated efforts in various fields of forestry. In addition, Teacher Awards were presented to Faculty for the unique characteristic that they bring to the program, to commemorate their talents, fortitude and their attitude towards the students and to forestry overall.

The Gold Medal Recipient for 2011 was awarded to Michael Nandan for being an exemplary model student to peers, parents and staff. Michael is a highly motivated, natural leader with a positive attitude, passion and drive. $\mathrm{He}$ served as the Forestry President for the 2010/2011 school year. During his term, he organized fund-raising events that reduced the cost of the graduation ceremony, and as well some of the funds were donated to Forests without Borders.
Michael continues to work in various aspects of the forestry industry and plans to further his studies in Europe to broaden his knowledge of European forestry techniques and how they might be introduced to support an even stronger forestry sector in Canada.

Overall, the celebration was a great success and its memory will serve as a reminder to the enjoyable learning experience the students had at Sir Sanford Fleming. Many thanks to the staff for their support and dedication to the students, and special thanks go out to all those who attended, those who put their time and effort into supporting student events; these efforts do not go unnoticed.

We are the stewards of the future and the instruments for the preservation of this amazing land, life and culture we have in Canada.

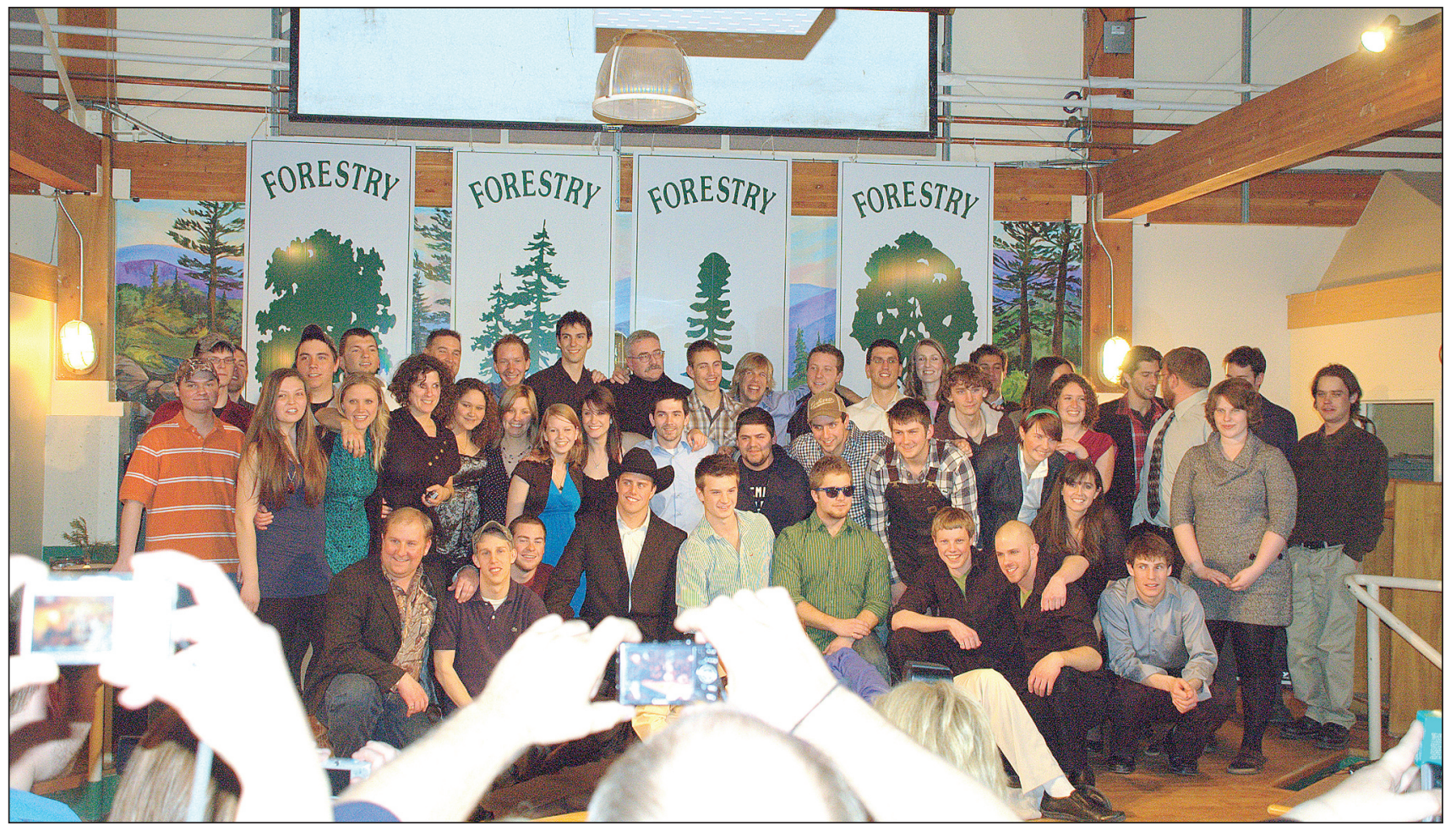

The 2011 Forestry Technician Graduating Class. 


\section{University of British Columbia}

he Class of 2011's Silver Ring Ceremony was held Saturday March 19th at the Four Seasons Hotel in downtown Vancouver. Three hundred and fortythree graduating students, family members, UBC Forestry alumni, CIF/IFC members, special guests, faculty and staff were present to enjoy this gala evening.

After a cocktail reception in the ballroom foyer, there was a formal dinner in the Park Ballroom. Dr. David Cohen, selected by the students as MC, did a fine job of welcoming and keeping everyone on time all evening, in fact managing to finish ahead of schedule which allowed for a longer "after party" for the students, friends and family members spry enough to stay late to dance the night away. Dr. Cohen's wit, charm and insightful remarks were much appreciated by all. The keynote speaker was Dr. John Innes, Professor and Dean of the Faculty, who presented himself in his Scottish kilt, considered to be respectful attire to honour "his students' clan". He spoke about his clan coat of arms ex labore dulcedo (with hard work comes sweetness) and gave an inspiring talk about pursuing knowledge and virtue, very appropriate for students to hear on the brink of graduation.

Chantelle Chan, Forestry Undergraduate Society (FUS) President and Christopher Burke, FUS Loggers Sport Representative, spoke about the highlights of student life from the perspective of Forestry Undergraduate Society members. They congratulated their classmates on their impending gradua- tion and other great achievements, and poked a bit of fun at fellow students and Faculty members. Chantelle and Christopher were joined on the stage by Tracy Wotten, FUS Treasurer and Amanda Harvey, incoming FUS President and provided Margaret and Angela (two retired custodial staff) with flowers and gifts to acknowledge their support to students through their many years of services to UBC.

The next speaker was Brian Scott, this year's CIF/IFC student representative who was also responsible for coordinating the Grad Committee and organizing the Silver Ring Ceremony. Brian spoke enthusiastically of the monthly CIF/IFC dinner meetings plus his fantastic and eventful trip to Jasper last fall for the CIF/IFC AGM and Conference, including the Student Quiz Bowl (we were able to sponsor three student teams to attend). He encouraged all students to continue their association with the CIF/IFC after receiving their silver rings and congratulated all of his peers on their imminent graduation.

After a short break, the evening resumed with Janelle Sakamoto and Emily Toda drawing the winning raffle tickets for the evening's grand prizes. This year, we exceeded any raffle held in the past and raised $\$ 1385$, which was a great boost to the event fund-raising.

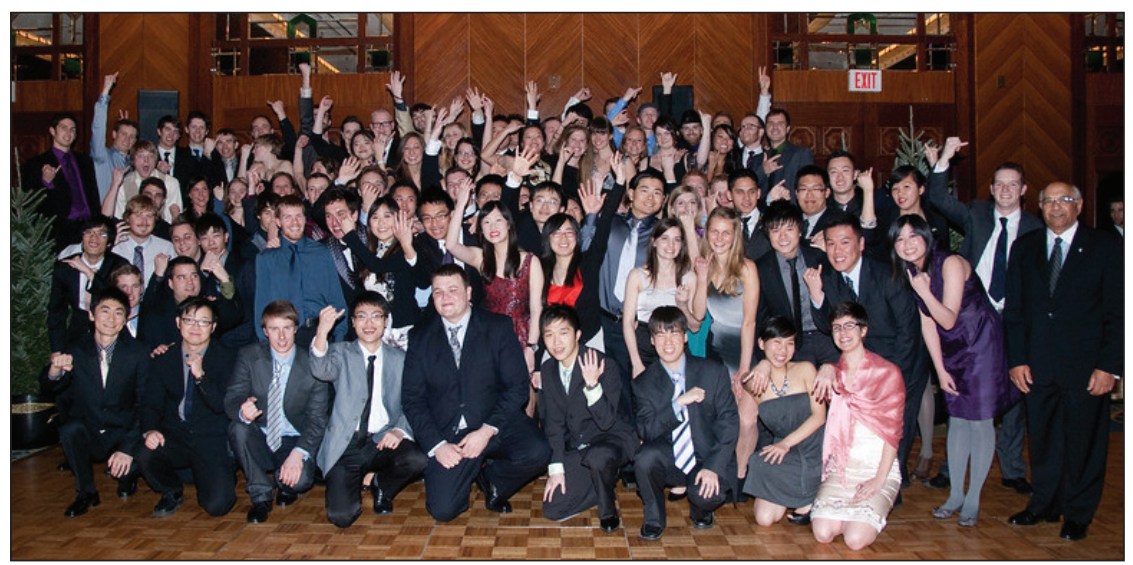

The Class Act of 2011

Wonderful prizes were given out to four lucky recipients (see sponsor list below).

The CIF/IFC Gold Medal for the most outstanding student in the Class of 2011 was presented by Chiara Longhi, UBC Forestry Advisor. Chiara is a "loud and proud" Italian who speaks very flamboyantly and with great enthusiasm. She started her remarks in Italian but luckily for the attendees eventually switched to English and presented the Gold Medal to Brian Scott, BSF Forest Operations student. This

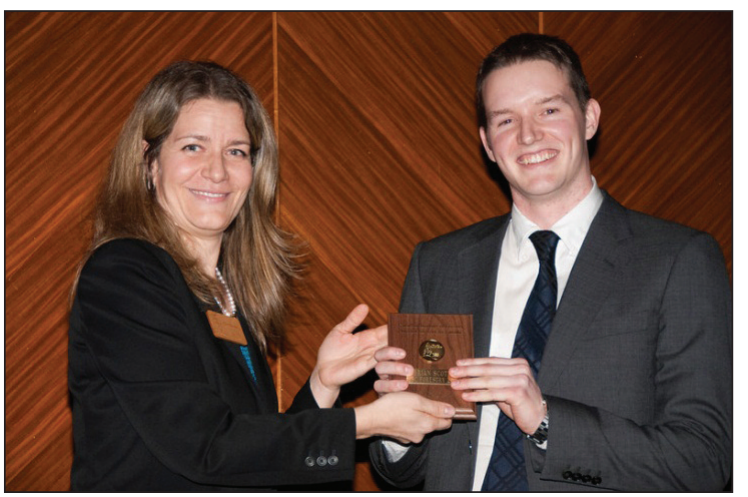

Chiara Longhi presents the CIF/IFC Gold Medal to Brian Scott of Victoria, B.C.

Award is based on excellent academics, good character, involvement in sports, volunteer work and Faculty and University affairs. It was difficult to keep this award a secret from Brian as he was so involved in the ceremony organization, but we succeeded and he was amazed and delighted to have been chosen.

The evening concluded with the Silver Ring Ceremony itself-the traditional presentation of rings to signify completion of an accredited Canadian Forestry degree program. UBC was the first school to present these rings and has been doing so since 1953 .

After a brief speech explanation of the Silver Ring importance, Dr. Peter Marshall, Associate Dean of Undergraduate Studies, handed over the podium to Michel Vallee, CIF/IFC National $2^{\text {nd }}$ Vice President, who reinforced the significance of the Silver Ring and the qualities of its recipients. $\mathrm{He}$ concluded by saying that the ring is there to remind us what kind of "Forestry Graduate" we should all strive to be. Dr. Marshall then read the names and brief write-ups (often very humorous) of the 84 Silver Ring recipients. 
Michel presented the rings, assisted by Chiara Longhi. A special ring presentation was made to Tom Pallan, the first Indo-Canadian to graduate from the UBC Forestry program in 1958. Tom started his own logging company (Pallan Lumber) in 1959 while pursuing a Forestry Master's degree from the University of Oregon. Dr. Cohen ended the evening by thanking everyone for attending, wishing all the graduates the best for their future.

It was a wonderful evening, great to see so many UBC Faculty and staff there to help celebrate the students' achievement in getting to this point in their career. Special guests included CIF/IFC members Mike Apsey, Gerry Burch, Janet Mitchell, Don Laishley and Association of BC Forest Professionals representative, Mike Larock. Much appreciation goes to Sandy McKellar for being the official photographer and to UBC Forestry Student Services staff for their organization and implementation of this event (Candace Parsons, Yuko Lee, Chiara Longhi and Geoff Anderson).

Thanks to the following generous sponsors:

Forestry Undergraduate Society $\$ 2500$ donation to sponsor the ring ceremony

Western Forest Products Inc. \$500 donation

Four Seasons Hotel - free hotel night including breakfast for two (raffle prize)

Hidden Restaurant - \$100 gift certificate (raffle prize)
Shaughnessy Restaurant at VanDusen Gardens - \$50 gift card (raffle prize)

UBC Food Services - \$50 gift card (raffle prize)

Evergrow Christmas Trees - four live potted trees to enhance the ballroom decor

Brinkman and Associates Reforestation Ltd. - donated seedlings for table centerpieces and souvenirs for graduates and guests

Association of BC Forest Professionals - donated ABCFP-ware (raffle prize)

Adopt-a-Student program - donations by individual Faculty and staff members to subsidize student tickets to the ring ceremony

Dr. Peter Marshall, Associate Dean and Professor, CIF/IFC Past President,

Vancouver Section Council member

\section{Forestry Mentoring Program}

Calling all UBC Forestry alumni! We're looking for volunteers to participate in the Forestry mentoring program for the 2011/12 academic year. The Forestry mentoring program matches an alumnus with a junior student and a senior student each year during the eightmonth school term. During this entire term you need only commit to 10 to 15 hours of time, and this can be in the form of meetings or correspondence by phone or email, whatever works best for you or your group. Your participation in the program allows students to gain valuable insight into life beyond university and provides guidance as they work to establish their career or future educational paths. You in turn will benefit from the program, meeting potential future employees, reconnecting with your almamater and feeling a sense of pride in giving back to the community in which you live and work.

If you are interested in learning more about the program or getting involved for this coming year, please contact Jenna McCann.

\section{We're Online, Are You?}

Have you been receiving the Faculty's monthly alumni e-newsletter? It is full of information on events, reunions, research and other Faculty news, relevant to those living close to UBC or thousands of kilometres away. If you'd like to start receiving the newsletter or if you have something to submit, contact us today. The Alumni Office has also established a group on LinkedIn to encourage networking amongst alumni; the Faculty has a Twitter account so you can get the latest news from your Forestry Faculty. Visit www.linkedin.com and search for UBC Forestry Alumni to join the group and check out twitter.com/ubcforestry. Contact: UBC Faculty of Forestry Alumni Office.

Jenna McCann, Alumni Relations Manager; jenna.mccann@ubc.ca

\section{University College of the North}

o n April 15, the Natural Resources Management Technology (NRMT) program was pleased to welcome students, their families, dignitaries, and individuals who have taught in the NRMT program to the fourth annual CIF/IFC Silver Ring ceremony. We were especially pleased to welcome Manitoba's new Section director, Brad Epp, whose palate had yet to experience the magnificent food created by the UCN Culinary Arts class. On centre stage (or centre table that is), was pork wellington and rabbit chasseur, and in the wings a supporting cast of potatoes au gratin with gouda, carrot Vichy, salmon, shrimp, mussels, scallops, lobster, and calamari. For those who still had room, the meal was topped off with decadent cheesecake and trifle. After some time to digest and for Brad's taste buds to calm down enough so that he could speak, it was time for the awards. The families of the ring recipients were on hand to watch as the students received their rings - now tradition. The presentation of the Gold Medal award this year went to a well-deserving Darby Branconnier, tying the score at two medals for the men and two for the 


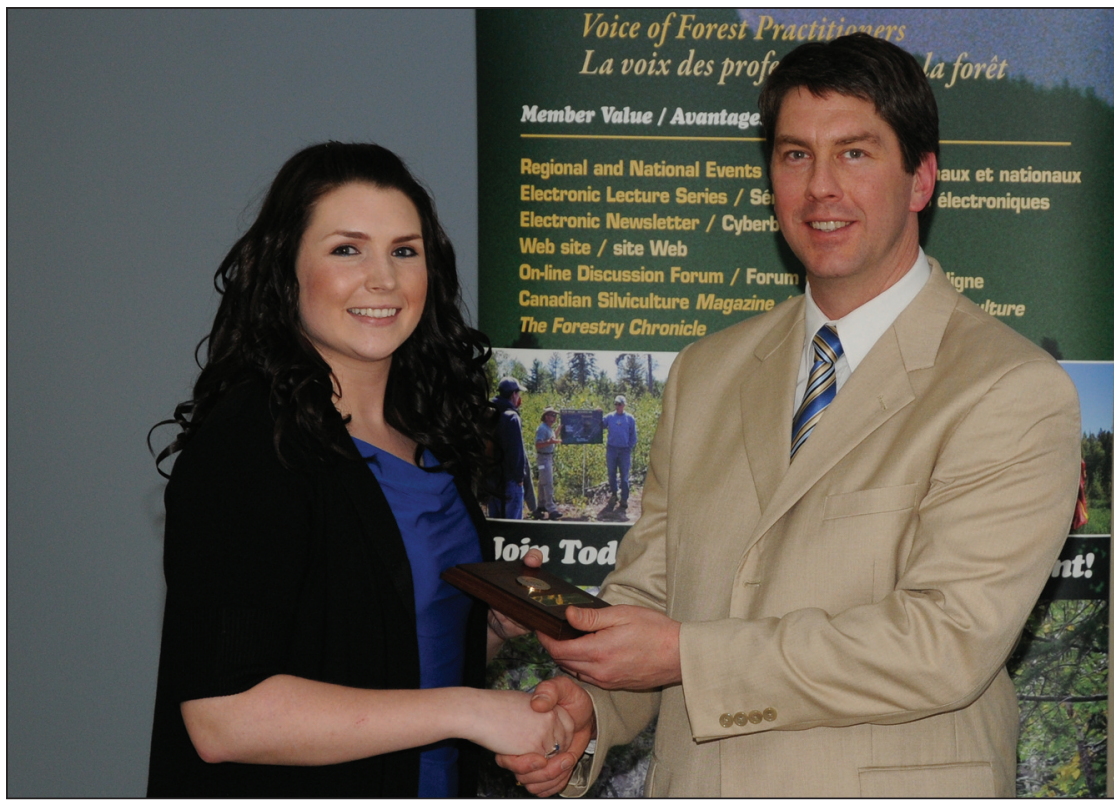

Darby Brannconnier receives the 2011 CIF/IFC Gold Medal from Manitoba Section Director, Brad Epp etc.

women. The Ring Ceremony is in its infancy at the University College of the North, and as is often the case, something was added to the growing tradition. This year, Pineland Tree Nursery of Hadashville, Manitoba donated white spruce seedlings as centrepieces for each table. When the awards were presented, it seemed only appropriate that we toast to the growing knowledge planted in each of the ring recipients being honoured. After the traditional clinking of the glasses filled with water and the drink that usually follows, everyone poured a bit of water from their glasses into the potted trees. It served as a symbol of nourishment for continued growth. The evening ended with photos and time for students, staff, guests, and families to mingle.

\section{UCN's Gold Medal Recipient for 2011}

Darby Branconnier grew up in Swan River, Manitoba, which is nestled in the centre of three provincial forests: Porcupine, Swan Pelican, and Duck Mountain. In this setting she found ample opportunity to enjoy the outdoors, and a love of them was inevitable. She was employed for two seasons with Louisiana Pacific Manitoba as a forest technologist, and it was during this time that the seed for more education in the field of natural resources took root and began to grow. The need for knowledge to feed that growth led her to the University College of the North's Natural Resources Management Technology program in The Pas. She says she gained a lot of knowledge at UCN that she will carry with her as her future unfolds. She is back working seasonally with Louisiana Pacific, which she hopes will lead to full-time employment.

\section{Selkirk College}

he Forest Technology program at Selkirk College held its annual Silver Ring Ceremony on Thursday, April 14. Fifteen Selkirk College graduates received their silver rings. The 2010 CIF/IFC Gold Medal Award went to Raquel Milaire. She was selected in recognition of outstanding scholarship, sportsmanship and citizenship throughout the Forest Technology program.

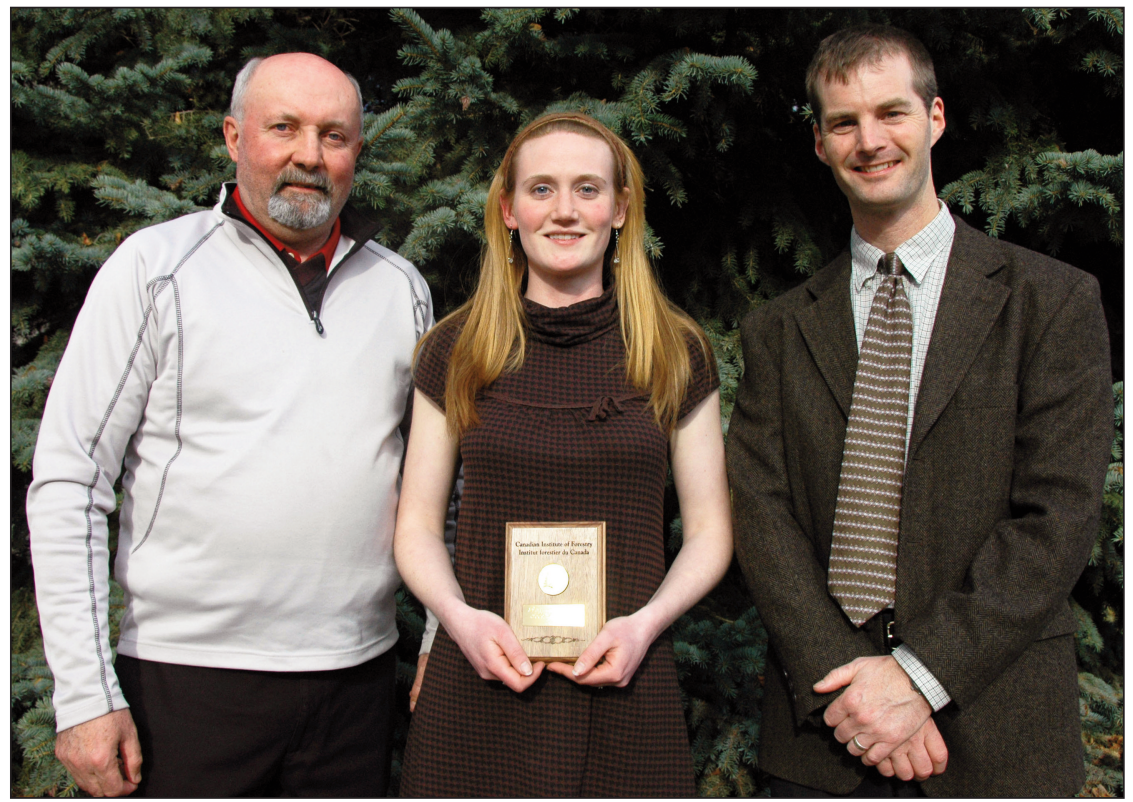

Standing $(L-R)$ : Forest Technology instructor Stu Deverney, Raquel Milaire and School of Renewable Resources Chair Derek Marcoux. 


\section{Université de Moncton}

c ette année, le finissant de la Faculté de foresterie (FdeF) de l'Université de Moncton, campus d'Edmundston (UMCE), Jonathan Synnott, s'est mérité, pour une deuxième fois, une Médaille d'or de l'Institut forestier $d u$ Canada (IFC).

Originaire de Gaspé, au Québec, Jonathan s'est distingué tout au long de ses études universitaires par son excellent rendement académique, ainsi que par son engagement et son implication à l'Université. En 2008, Jonathan a complété ses premières études en foresterie dans le programme de technologie forestière au Cégep de Gaspésie et des Îles. À ce moment, il fut décerné la médaille d'or de l'IFC pour les finissants de ce programme. À l'automne de la même année, il a transféré au programme de Baccalauréat en sciences forestières, régime régulier, de la Faculté de foresterie de l'UMCE. Dès sa première année à notre institution, il s'est impliqué activement dans les activités étudiantes. En 2009-2010, il occupait le poste de conseiller au sein du Conseil étudiant de la FdeF, soit une année où les étudiants de la FdeF se méritaient le titre de "Secteur de l'année". En 20102011, Jonathan assumait la présidence du Conseil. Cette même année, il a été un contributeur (recherche, rédaction de dépêches) pour le site internet

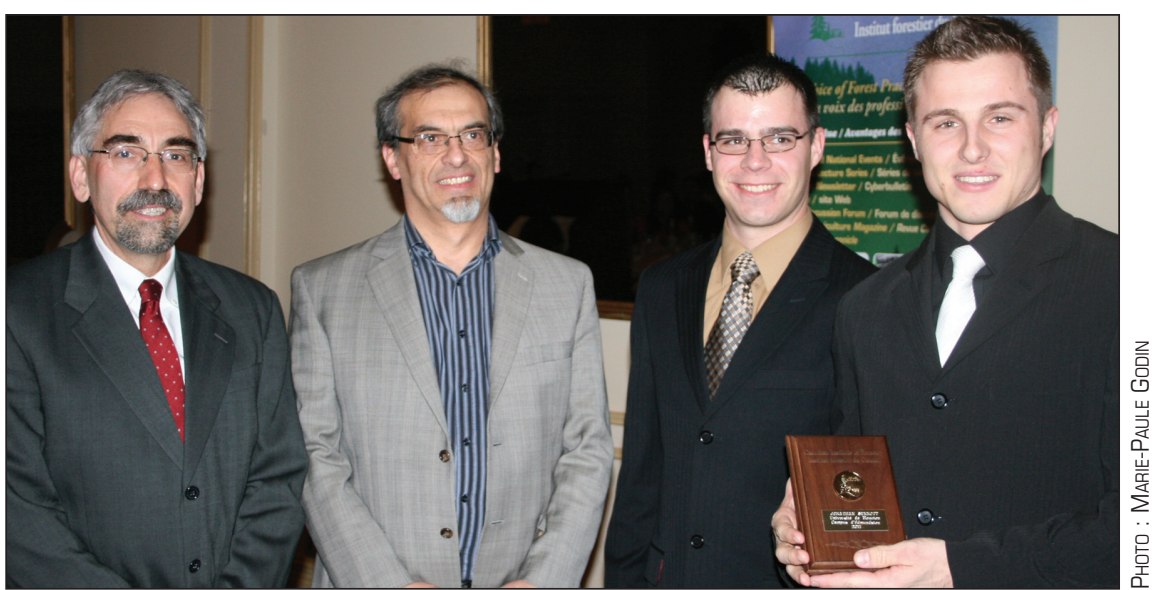

Médaille d'or de l'Institut forestier du Canada (IFC) 2011 : De gauche à droite : Roger Roy, professeur FdeF; Jean-Marie Binot, doyen FdeF; Éric Labelle, Institut forestier du Canada; Jonathan Synnott, médaillé.

"Médiaterre" (portail du NouveauBrunswick), soit un site web d'information mondiale sur le développement durable. Dans le domaine sportif, Jonathan a été très engagé au fil des ans dans la pratique du karaté Shotokan. Jonathan est aussi membre de l'Institut forestier du Canada depuis 2010.

Jonathan a profité de ses étés pour acquérir de l'expérience de travail en foresterie, et ce dans des domaines très diversifiés. Il a réalisé plusieurs stages avec des entreprises agricoles et forestières de la péninsule Gaspésienne, entres autres comme technicien fores- tier en forêt privée (plans d’aménagement forestier, projet dérablières, parc éolien, lignes de transmission, etc.). En ce qui concerne sa carrière future, il a un intérêt marqué pour la forêt privée et pour la gestion de projets reliés à la foresterie. Pour l'instant, il a accepté un poste d'ingénieur forestier avec Les Entreprises agricoles et forestières de la Péninsule Inc. (EAFP) à Gaspé. Il a l'intention de développer une expertise dans ce domaine et plus tard, lorsque loccasion se présentera, devenir directeur d'entreprise.

\section{BOOK ANNOUNGEMENTS \& PUBLICATIONS RÉEENTES}

\section{Reaching for the Sun - How Plants Work 2nd dedition}

John King, 2011. ISBN: 978-0-521-73668-8. Cambridge University Press, New York. US \$39.00 + shipping (paperback). Contact: publicity@cambridge.org

rom their ability to use energy from sunlight to make their own food, to combatting attacks from diseases and predators, plants have evolved an amazing range of life-sustaining strategies.

Written with the non-specialist in mind, Dr. John King's lively natural history explains how plants function, from how they gain energy and nutrition to how they grow, develop, and ultimately die. New to this edition is a section devoted to plants and the environment, exploring how problems created by human activities, such as global warming, pollution of land, water, and air and increasing ocean acidity, are impacting on the lives of plants.

King's narrative provides a simple, highly readable introduction, with boxes in each chapter offering additional or more advanced material for readers seeking more detail. He concludes that, despite the challenges posed by growing environmental perils, plants will continue to dominate our planet.

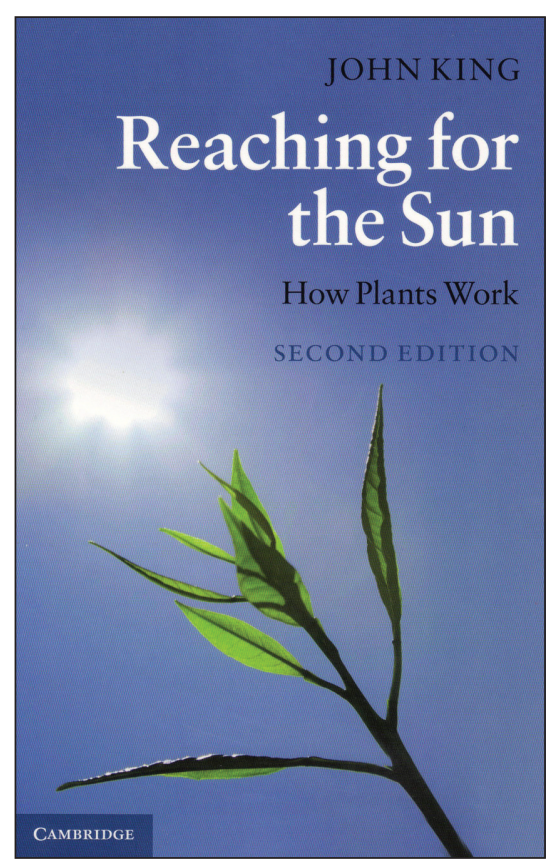

